\title{
Skin ulcer presentation of Wegener's granulomatosis
}

\author{
Conleth Feighery, ${ }^{1,2}$ Niall Conlon, ${ }^{1}$ Mohamed Abuzakouk ${ }^{2}$ \\ ${ }^{1}$ Department of Immunology, Trinity College Dublin \& St. James's Hospital, Dublin, Ireland \\ ${ }^{2}$ Department of Immunology, St. James's Hospital, Dublin, Ireland \\ Correspondence to Conleth Feighery, con.feighery@tcd.ie
}

\section{DESCRIPTION}

A 49-year-old male presented with a 6-week history of a single ulcer ( $3 \mathrm{~cm}$ diameter) on his left leg some $8 \mathrm{~cm}$ above the lateral malleolus. The $4 \mathrm{~cm}$ ulcer had a well-demarcated edge and the base appeared mildly infected (figure 1A). His only additional complaint was of intermittent musculoskeletal pain for the previous 4 months. The pain involved the thoracic cage, cervical spine, hands, shoulders and knees. Physical examination was normal except for the presence of the ulcer. Features of leukocytoclastic vasculitis were observed in a biopsy of the ulcer. Autoantibody serology was strongly positive for cytoplasmic antineutrophil cytoplasmic antibody (C-ANCA) and anti-PR3 autoantibodies. A diagnosis of Wegener's granulomatosis was made and he responded to oral cyclophosphamide and prednisolone (figure 1B). He remained in complete remission for 4 years and then re-presented with a systemic pyrexial illness and associated ear and eye inflammation. A chest x-ray showed an opacity in the mid-zone of the right lung. A positive C-ANCA test was again noted. Based on his previous presentation, the current clinical picture and the positive autoantibody serology, a diagnosis of Wegener's granulomatosis in relapse was made. He was treated again with immunosuppressive drugs and 4 years later (April 2010) remains well, off all therapy.

This case demonstrates how Wegener's granulomatosis can present in an atypical manner and the variable nature of this disorder. ${ }^{2}$ The value of the C-ANCA investigation is also highlighted, since in the absence of a positive autoantibody test, it is doubtful that the correct diagnosis would have been made at first presentation.

\section{Competing interests None.}

Patient consent Obtained.

\section{REFERENCES}

1. Stewart C, Cohen D, Bhattacharyya I, et al. Oral manifestations of Wegener's granulomatosis: a report of three cases and a literature review. J Am Dent Assoc 2007;138:338-48; quiz 396, 398

2. Chang YJ, Kerr LD. Isolated abdominal vasculitis as an atypical presentation of Wegener's granulomatosis. Am J Gastroentero/ 2000;95:297-8.
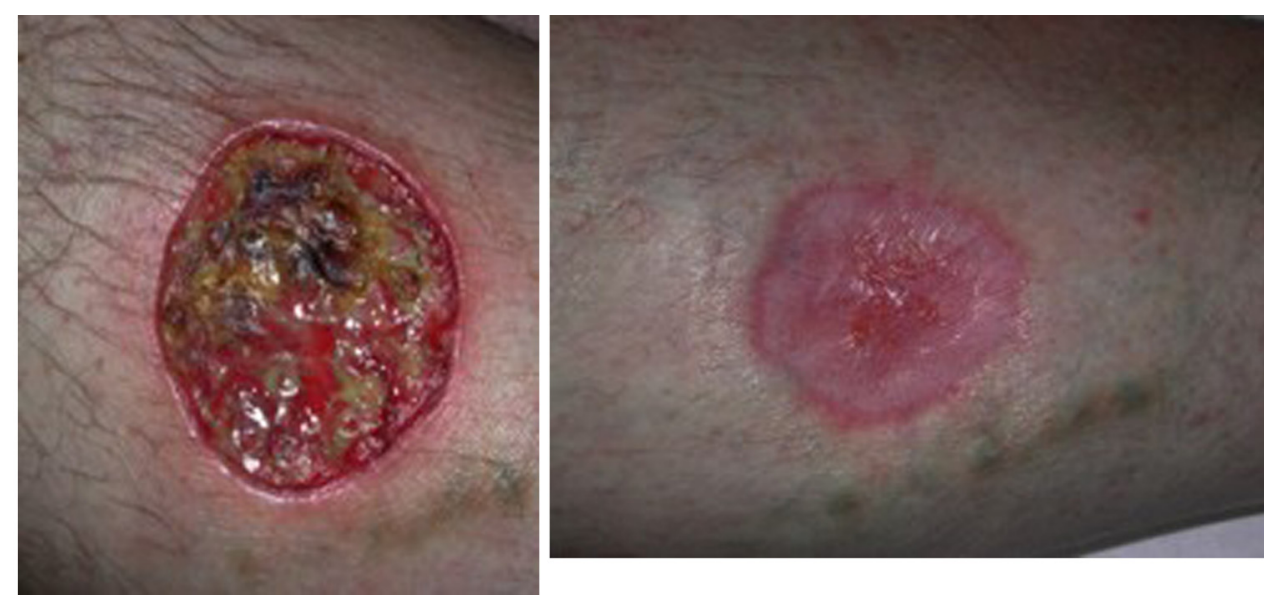

Figure 1 (A) Well-demarcated $4 \mathrm{~cm}$ ulcer was found above the lateral malleolus of the left leg with almost complete healing of the lesion after immunosuppressive therapy (B). 


\section{BMJ Case Reports}

This pdf has been created automatically from the final edited text and images.

Copyright 2010 BMJ Publishing Group. All rights reserved. For permission to reuse any of this content visit http://group.bmj.com/group/rights-licensing/permissions.

BMJ Case Report Fellows may re-use this article for personal use and teaching without any further permission.

Please cite this article as follows (you will need to access the article online to obtain the date of publication).

Feighery C, Conlon N, Abuzakouk M. Skin ulcer presentation of Wegener's granulomatosis. BMJ Case Reports 2010;10.1136/bcr.04.2010.2908, date of publication

Become a Fellow of BMJ Case Reports today and you can:

- Submit as many cases as you like

Enjoy fast sympathetic peer review and rapid publication of accepted articles

Access all the published articles

Re-use any of the published material for personal use and teaching without further permission

For information on Institutional Fellowships contact consortiasales@bmjgroup.com

Visit casereports.bmj.com for more articles like this and to become a Fellow 